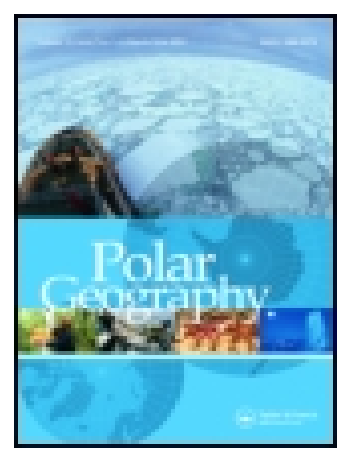

Polar Geography

ISSN: 0273-8457 (Print) (Online) Journal homepage: https://www.tandfonline.com/loi/tpog19

\title{
Pingos and palsas: A review of the present state of knowledge
}

\section{Albert Pissart}

To cite this article: Albert Pissart (1985) Pingos and palsas: A review of the present state of knowledge, Polar Geography, 9:3, 171-195, DOI: 10.1080/10889378509377249

To link to this article: https://doi.org/10.1080/10889378509377249

册 Published online: 23 Dec 2008.

Submit your article to this journal 준

Ц Article views: 17

Q View related articles $\asymp$

4 Citing articles: 5 View citing articles 


\title{
PINGOS AND PALSAS: A REVIEW OF THE PRESENT STATE OF KNOWLEDGE
}

\author{
Albert Pissart \\ (Department of Geomorphology and Quaternary Geology, \\ University of Liege)
}

From: Inter-Nord, No. 17, 1985, pp. 21-32.

\begin{abstract}
The article presents a summary of the present state of knowledge of perennial periglacial mounds, including descriptions of the external appearance and internal composition of pingos and palsas and a discussion of the genetic mechanisms. Pingos appear to be the result of the freezing of a mass of water trapped beneath permafrost under cryostatic or hydraulic pressure. Palsas are formed by the migration of groundwater to a freezing plane (cryosuction). The existence of mineral palsas is recognized; in this case the peat cover may be extremely thin or even totally non-existent.
\end{abstract}

\section{INTRODUCTION}

Pingos and palsas are periglacial mounds which can exist only in the presence of permafrost. Both types of mound correspond to local accumulations of ice which have raised overlying surficial layers of earth materials.

The distinction between pingos and palsas is obvious, at least in the majority of cases. As we will see later the mechanisms which give rise to them are not in fact the same. And yet there exist intermediate periglacial mounds where it is difficult to determine which would be the most appropriate name to use. The uncertainty in the terminology becomes even more apparent when it comes to giving a name to mounds which appeared during the cold periods of the Quaternary, in regions which are now temperate. In order to be able to interpret the surviving traces of these forms a thorough knowledge of those existing in present periglacial regions is clearly indispensable. This is one of the aims of the synthesis which will be presented below.

Several articles, similar to this one in that they discuss palsas and pingos, have already appeared. On this subject I would cite especially the publications of Maarleveld (1965), Barr and Syroteuk (1973), Washburn (1973, 1979), Jahn (1975), French (1976), Mackay (1979) on the topic of pingos; those of Lundquist (1969), Ahman (1977) on the topic of palsas; and finally those of Pissart (1974) and Flemal (1976) on fossil forms.

The following discussion will deal successively with pingos then palsas. Their general characteristics will be presented and the mechanisms which give rise to them will be studied. 


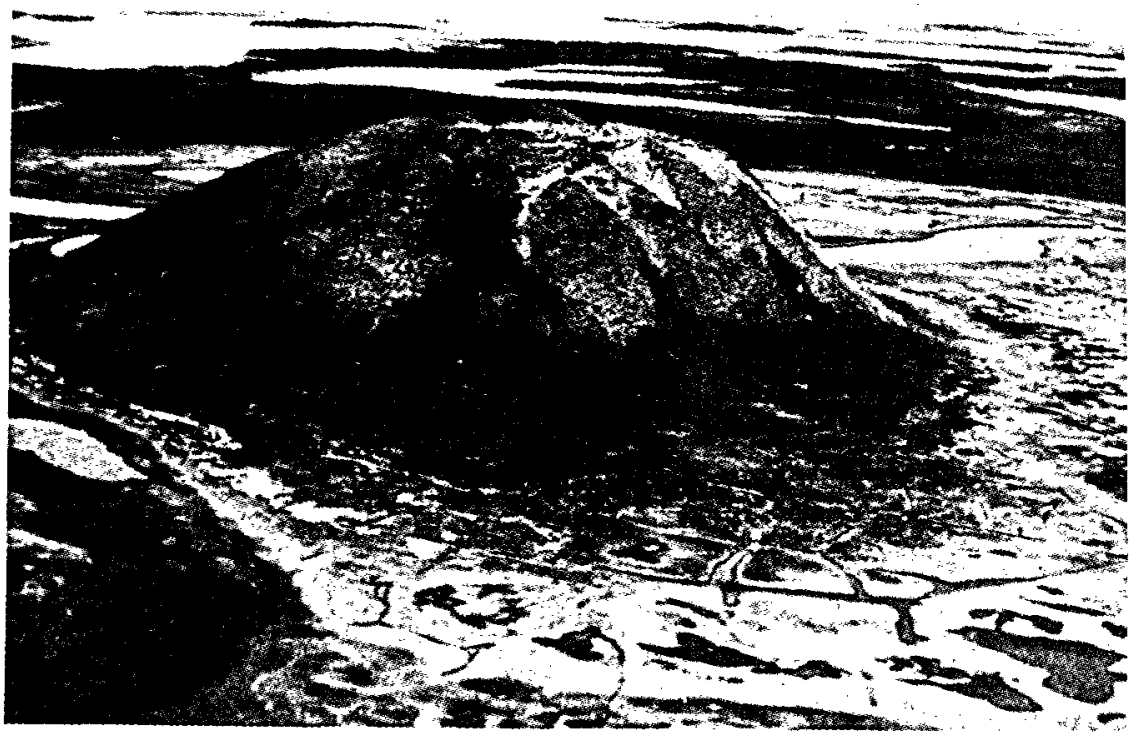

Fig. 1. The Ibyuk pingo, east of the Mackenzie Delta near Tuktoyaktuk; it has been studied by Müller (1959) and by Mackay (1976). Height: $48 \mathrm{~m}$. Amount of growth in 2 years (1973-75): $2.8 \mathrm{~cm}$.

\section{PINGOS}

\section{Description}

Terminology. The Inuktitut word pingo was first used by Porsild in 1929 and was proposed by him as a technical term in 1938. Since then it has been widely accepted and used in the Western literature. The Russians most commonly use the terms bugor, bulgunniakh, or hydrolaccolith. According to Washburn (1979), the first two of these terms could indicate palsas equally as well as pingos.

External Characteristics. Pingos are mounds which most commonly are conical in shape. The highest attain heights of $50 \mathrm{~m}$. The Ibyuk pingo near Tuktoyaktuk, just east of the Mackenzie Delta, probably the best-known pingo since it has been the object of investigations by Fritz Müller (1959) and Ross Mackay (1976;1979), is $48 \mathrm{~m}$ high. It is probably the highest pingo on the Tuktoyaktuk Peninsula where 85 percent of the pingos are less than $20 \mathrm{~m}$ in height (Mackay, 1969, p. 26).

In 1919, using a barometer, Leffingwell measured a pingo $70 \mathrm{~m}$ high, but to my knowledge no author since then has recorded any comparable pingo height. In 1962 (p. 26) Mackay described pingos $3 \mathrm{~m}$ in height and in 1979 (p. 15) pingos only $1 \mathrm{~m}$ in height, demonstrating that as far as he is concerned the term pingo may be applied 
equally well to quite small forms. The diameters of pingos vary between 30 and 600 m (Mackay, 1962). Generally pingos are very wide and low, or else not so wide and higher (Mackay, 1979).

While the most typical pingos are circular in plan, elongated forms do exist (Müller, 1959; Mackay, 1966; Pissart, 1967; Tarnocai and Netteville, 1976; Rotnicki and Babinski, 1977; Pissart and French, 1976; Liest $\phi 1,1977)$. Some pingos are so long that they resemble eskers; Mackay (1966) has described one $600 \mathrm{~m}$ long and $7.6 \mathrm{~m}$ high in the Mackenzie Delta; while Pissart (1967) observed a form $1300 \mathrm{~m}$ long and locally reaching heights of $8.75 \mathrm{~m}$ on Prince Patrick Island (Canada).

When a pingo has grown sufficiently, the layer of sediments which have been uplifted will crack. A pattern of cracks with a radial arrangement and coverging towards the summit of the pingo will appear. As they widen, these cracks permit the melting of the underlying ice core. A depression thus develops in the summit of the mound, initiated by the simple mechanical action of the uplift; it develops by means of thermokarst processes. From its location in the summit of the mound this depression resembles a volcanic crater. It is most commonly occupied by a small pond.

The slopes of pingos are highly variable. Mackay $(1973 ; 1978 ; 1979)$ has demonstrated that the initial mound widens very little during the growth process; as a result the slopes steepen progressively as the pingo develops. Müller (1959) has indicated that the outer slopes may locally reach $40^{\circ}$, although Barr and Syroteuk (1973) and Mackay (1978) indicate that the slopes rarely exceed $45^{\circ}$. However, Mackay $(1969, \mathrm{p}$. 11) has described a pingo slope reaching $50^{\circ}$; it rose from the shores of a pond $2.5 \mathrm{~m}$ deep. Within the crater, which widens as the underlying ice core melts, the slopes are much shorter and may approach the vertical (Müller, 1959).

Sometimes a concentric network of cracks accompanies the radial cracks. Mackay (1973) compared them with the cracks which appear when laccoliths are intruded and stated in 1977 that in the case of "pulsating pingos" the uplift by the water is similar to the uplift achieved by magmatic rocks. Similar concentric cracks had been described earlier (Mackay and Stager, 1966; Müller, 1959; Rampton and Mackay, 1971; Washburn, 1973).

Internal characteristics. The ice responsible for the mound often takes the form of an enormous lens resulting from the freezing of injected water; Mackay (1971; $1973 ; 1978)$ has insisted that segregation ice may also exist in large quantities in the ice core of pingos.

The existence of a lens of free water lifting both the ice core and the overlying sediments has recently been demonstrated in the case of some pingos near the Mackenzie Delta on the basis of levellings. These indicated that the forms rise then fall a few centimeters over a period of a few months or even a few days, hence the term pulsating pingo coined by Mackay (1977). Mackay later reached pockets of underlying water by drilling (1978). 
The materials uplifted by the ice core are highly varied in nature. They consist of unconsolidated materials ranging from silts to gravels, but sometimes even bedrock such as sandstone (Muller, 1959; \&hman, 1973) and schists (Balkwill et al., 1974). In some cases a more silty layer has been observed in contact with the ice (Pissart, 1967; Pissart and French, 1976; Soloviev, 1952). The thickness of the displaced layer also varies considerably; clearly it must exceed the thickness of the active layer, otherwise the ice would melt, resulting in annual mounds. Mackay (1962) has quoted the thickness of the uplifted layer in the case of various mounds. The largest observed thickness appears to be $14 \mathrm{~m}$ in the case of the Ibyuk pingo near Tuktoyaktuk (Müller, 1959).

Growth rates. Growth rates of pingos have rarely been observed. Mackay (1973, p. 382), who has devoted an article to the study of this question, mentions that according to Shumskii (1964) uplift varies from an almost imperceptible movement to more than $0.5 \mathrm{~m}$ per year. He also mentions that in 1964 Suslov reported growth rates of 1.5 to $2.0 \mathrm{~m}$ in 20 years, based on the statements of the indigenous people. More precise data resulted from an important program of levelling carried out by Mackay $(1973 ; 1976 ; 1977 ; 1979)$ over several years $(1969-1978)$ just east of the Mackenzie Delta. These measurements show clearly that pingos rise most in the center with the movement diminishing towards the sides; hence pingos rise vertically rather than growing both laterally and vertically at the same time. The most rapid observed growth rate was $1.5 \mathrm{~m} / \mathrm{year}$ for the first two years; subsequently the growth rate varied inversely with the square root of elapsed time (Mackay, 1973). However in 2 years (1973-75) the Ibyuk pingo, which is $48 \mathrm{~m}$ high and may be 1000 years old (Mackay, 1976), rose by $2.8 \mathrm{~cm}$. An uplift of $34 \mathrm{~cm} /$ year over the period 1974-78 was observed in the case of a pingo $12 \mathrm{~m}$ high. This is the most rapid growth rate ever measured for a well-developed pingo (Mackay, 1979). It is interpreted as resulting from the injection of a lens of water, since the growth rate exceeds the possible rates of uplift due to the expansion of water freezing at depth.

Traditionally, since Porsild's publication in 1938 two genetically different systems have been proposed to explain the origin of pingos; these have been named the "open system" and the "closed system." Other hypotheses which have been evoked to explain pingos have been briefly presented and criticized by Mackay (1979). I shall limit myself to discussing here only those theories which appear to have withstood criticism.

\section{Genetic Mechanisms}

\section{Closed system pingos}

The process. The pingos east of the Mackenzie Delta are the best-known forms in the world. They are variously known as closed system pingos or Mackenzie-type pingos. These pingos, like those of Central Yakutiya, which are of the same origin, are generally located on the sites of former lakes. This was the case with 90 percent of the 1,380 pingos mapped by Stager in the Tuktoyaktuk Peninsula area (1956). These play a role in determining the mechanism which gives rise to them. The basic principle, enunciated for the first time by Porsild in 1938, has subsequently been fleshed out and elaborated by numerous authors. 

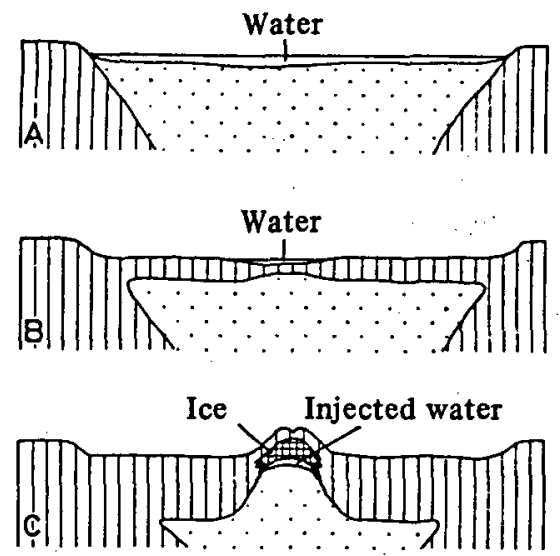

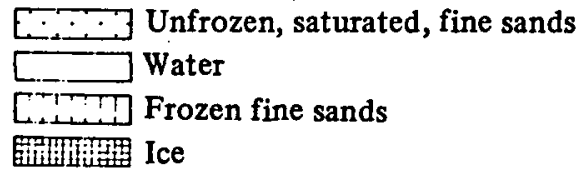

Fig. 2. Origin of closed system or Mackenzie type pingos, according to Mackay's (1979) diagram.

In regions where the permafrost is thick enough (several hundred meters in Central Yakutiya and certainly 400 to $600 \mathrm{~m}$ or more east of the Mackenzie Delta, according to Judge et al., 1979) a talik (non-frozen zone) exists beneath certain lakes, specifically those which are deep enough. This unfrozen zone is to be explained in part by the fact that these lakes do not freeze to the bottom in winter; in part it is because in summer solar radiation penetrates the lakes resulting in a considerable heat influx. This is much greater than in the case of adjacent land areas where part of the heat is reradiated to the atmosphere. Thus the temperature of the bed of the lake is distinctly higher than that of the surrounding ground surface.

If due to a lowering in the lake level (or to sedimentation) the depth of the water layer decreases, the bed of the lake will start to freeze. Thus beneath the bed of the former lake a pocket of unfrozen sediments is formed, completely enclosed on all sides. Porsild (1938) compared the phenomenon with that produced in a bottle filled with milk which is subjected to freezing. The increase in volume accompanying the freezing of the water results in the case of the closed cell which constitutes the pocket of unfrozen sediments, in an increase in pressure which will give rise to an injection of water towards the surface.

Sometimes this injected water may reach the surface where it will flow away or, if the phenomenon occurs in winter, it will accumulate as an icing (Shumskii, 1959; Mackay, 1973). If, on the other hand, compressed gases have accumulated in the mass of water, the rupture of the cover may be accompanied by a spout of water or mud 
several meters high and sometimes even by an explosion, throwing pieces of the cover into the air (Shumskii, 1959). Most commonly, however, the water is retained within the ground at shallow depth beneath a layer of sediments a few meters thick which is bulged upwards. This pocket of water subsequently freezes in situ, thus producing what is termed injection ice, i.e., ice resulting from the freezing of a mass of water injected into the ground.

The validity of this proposed mechanism has been confirmed by various observations. Thus the mechanism of lake drainage, followed by the growth of a pingo has been precisely observed from a sequence of air photos (Mackay, 1973; 1976) taken in 1935 (when the lake still existed), in 1950 (when the lake had drained due to coastal erosion), and in 1976 (when 4 pingos had formed in the lake bed on the sites of 4 ponds which still survived in 1950). Two of the pingos which had appeared exceeded $6.5 \mathrm{~m}$ in height by 1978 .

The existence of pockets of non-frozen sediments beneath Arctic lakes has been observed, most notably by Johnson and Brown (1961). As mentioned earlier, Mackay $(1977 ; 1978 ; 1979)$ has demonstrated the existence of pockets of water beneath growing pingos. The hydrostatic pressure of the water is sometimes sufficient to lift not just the pingo but sometimes the entire lake bed. Thus in the Mackenzie Delta the bottom of a lake underlain by $55 \mathrm{~m}$ of permafrost dropped by $2.5 \mathrm{~cm}$ after the drilling of a hole which allowed the escape of the water under pressure (Mackay, 1979, p. 23). Assuming a density of $2 \mathrm{~g} / \mathrm{cm}^{3}$ the hydrostatic level must have been $35 \mathrm{~m}$ above the lake level. However, Mackay has stressed (1979, p. 9) our general ignorance as to the origins of the closed system. It may result either from permafrost entirely surrounding a talik, or by the presence of an unfrozen pocket constrained laterally by frozen sediments and at depth by an impermeable layer, or again the system may not be completely closed, so that the water may escape slowly at depth.

The type of ice. Mackay $(1971 ; 1973 ; 1978)$ has introduced significant modifications to this scheme. On the basis of theoretical considerations which we will examing below, he believes in fact that within the core of a pingo segregation ice is very abundant, and that it may even occupy a more important place than injection ice (1973, p. 999). However, this injection ice appears within the core of the pingo because the water is under pressure. Hence in every case this pressure constitutes the fundamental mechanism for the appearance of pingos.

Mackay (1978, p. 141) cites references to more than 25 authors who have described the existence of segregation ice in pingos, in both closed and open systems from the USSR and North America. He adds (Mackay, 1978, p. 142) that observations made in the frozen cores of 17 pingos in the Tuktoyaktuk area (east of the Mackenzie Delta) have revealed that 2 pingos contained only cores of frozen sediment with a high ice content, 5 contained segregation ice and sediments, 4 contained both segregation ice and injection ice, and only 6 were composed entirely of injection ice. The description of the first two frozen cores does not permit an interpretation of the type of ice responsible for the uplift of the ground. Moreover, identification of the causal mechanisms is not always possible even when one can observe the ice, as is indicated 
by the article by Gell (1978), who carefully studied samples of ice taken from 3 different pingos.

The significance of segregation ice in pingos is still a matter of debate. While it is certain that lenses of segregation ice exist in the cores of certain pingos, it is possible that this type of ice represents only a very small part of the ice which has accumulated.

The origin of the pressure exerted on the water, as first invoked by Porsild in 1938 , derives from the volume increase ( \pm 9 percent) accompanying the change from water to ice. If the mass of water exists in a closed system which constrains this expansion, the change of phase does not occur; the water remains in the liquid state but its pressure increases. This pressure becomes increasingly great as the temperature drops; it may exceed $2,000 \mathrm{~kg} / \mathrm{cm}^{1}$ at a temperature of $-22^{\circ} \mathrm{C}$. However, the pressures involved in the formation of pingos do not reach such high values as this. A few $\mathrm{kg} / \mathrm{cm}^{2}$ would be sufficient to explain the forms which we are now studying.

In coarse sediments such as sands or gravels, as long as the sediments are completely saturated, the increase in volume at the moment of freezing of the interstitial water has the effect of causing expulsion of water from the sediment. The water moves freely between the pebbles or grains of sand. If this water cannot escape it will lift the overlying ground.

In fine sediments the processes are more complex. Two phenomena operate concurrently: water is sucked towards the freezing front (giving rise to segregation ice), or water is expelled, comparable to what happens in coarse sediments. The minimum pressure which provokes the switch from one type of behavior to the other is termed the "shut-off pressure." It may be determined in the laboratory.

In applying the data presented in Table 1 , one should note that in the absence of other phenomena, in fine silts, assuming a sediment density of $2 \mathrm{~kg} / \mathrm{cm}^{2}$, a sediment thickness of $2.5 \mathrm{~m}$, which corresponds to an overlying pressure of $0.5 \mathrm{~kg} / \mathrm{cm}^{2}$, is sufficient to prohibit the appearance of any segregation ice.

However, Mackay $(1971 ; 1973 ; 1978)$ has stressed that if the interstitial water is itself under pressure, that pressure will counteract the effect of the pressure, thus limiting the possibility of segregation ice formation.

The formula used by Mackay $(1979, \mathrm{p} .35)$ to express the possibility of the appearance of segregation ice is that proposed by Everett (1961) and by Williams (1967). The formula may be written:

$$
0<\mathrm{p}_{\mathrm{t}} \cdot \mathrm{p}_{\mathrm{W}}<2 \frac{\sigma}{\mathrm{r}}
$$

where $\mathrm{p}_{\mathrm{t}}$ is the pressure opposing the uplift due to freezing, i.e., the pressure of the overlying sediments, plus the resistance to deformation if the uplift is accompanied by deformation of the sediments; $\mathrm{p}_{\mathrm{W}}$ is the pressure of the water at the ice contact; $\sigma$ is the ice/water surface tension; $r$ is the radius of the largest interstices in the material. 


\section{TABLE 1}

Pressures (in $\mathrm{kg} / \mathrm{cm}^{2}$ ) Which Limit the Appearance of Segregation Ice Where the Interstitial Water Is Not Itself Under Pressure

(after Williams (1967) and Mackay (1971))

\begin{tabular}{lc}
\hline \multicolumn{1}{c}{ Type of material } & Pressure $\left(\mathrm{kg} / \mathrm{cm}^{2}\right)$ \\
\cline { 2 - 2 } Coarse sand & 0 \\
Medium-grained and fine sand & $0-0.075$ \\
Medium-grained silt & $0.075-0.15$ \\
Fine silt & $0.15-0.5$ \\
Silty clay & $0.5-2$ \\
Clay & 2 \\
\hline
\end{tabular}

The term on the right side of this equation, i.e., $2 \frac{\sigma}{r}$ is typical of the material used. The values which correspond to it, as measured in the laboratory, are given in Table 1.

Hence this equation shows that segregation ice may appear at any depth and at any pressure as long as the interstitial pressure is slightly below the pressure necessary to raise the overlying material. (If $\mathrm{p}_{\mathrm{W}}$ becomes greater than $\mathrm{p}_{t}$, injection of water occurs, hence the need for the term $0<\mathrm{p}_{\mathrm{t}} \cdot \mathrm{p}_{\mathrm{W}}$.)

On the basis of this equation and of Table 1, one can determine that in coarse sands segregation ice cannot appear at all, in any fashion. The possibility of it forming in medium-grained and fine sands, and indeed in medium-grained silts, is very low (Table 1). For that to occur the pressure must not be either greater than or less, by an amount of less than $0.15 \mathrm{~kg} / \mathrm{cm}^{2}$ (Table 1), than the pressure necessary to lift the overlying layer. For this situation to persist it is necessary that the amount of cold reaching the location where the segregation ice forms corresponds to the amount of water expelled from the sediment. In fact, if the entire mass of expelled water does not freeze to form the lens of segregation ice, the pressure rises and water is injected. Subsequently, even if the pressure drops back to a level favorable to the appearance of segregation ice, the pocket of free water which has appeared within the permafrost prevents the formation of new segregation ice.

If one considers finer sediments such as silts, for which the values of the "shut-off pressure" are higher (Table 1) the appearance of segregation ice is easier to understand; on the other hand its formation is complicated by the low permeability of the material.

Hence, on the whole, the appearance of segregation ice appears to occur quite rarely beneath pingos. It can form, as Mackay has demonstrated, but in my opinion it constitutes only a small part of the total amount of ice forming the core of a pingo. 

bed

Closed system pingos, such as those east of the Mackenzie Delta, are classically located on the sites of former lakes, and, as we have seen, are associated with the evolution of the latter. Pingos which are entirely comparable in origin have been described in connection with other phenomena which result in the appearance of a talik which subsequently freezes. Here are the examples known at present.

Pingos which appear in connection with river courses. In 1963 Mackay (p. 89) observed that some pingos in the modern delta of the Mackenzie had appeared on the sites of abandoned channels. Some of them were elongated in form and were aligned in a sequence along the former channel.

In 1976 Pissart and French described 17 pingos, the highest reaching $14 \mathrm{~m}$ in height, in the middle of the alluvial plain of the Thomson River and its tributary, Able Creek, on Banks Island (Canadian Arctic). Very similar forms have been described from elsewhere on Banks Island by French and Dutkiewicz (1976) and also from Mongolia by Rotnicki and Babinski (1977) and from China by Shaoling and Heqing (1981). They all appear to be linked to the appearance of taliks beneath river channels which subsequently freeze following the lateral displacement of the river.

Pingos related to fluctuations in sea level. On Prince Patrick Island Pissart (1967) has described the existence of pingos which appear to be related to fluctuations in sea level. They are located on alluvial plains, immediately adjacent to the sea. Sea level fluctuations would have given rise to the formation of a ria beneath which the permafrost would have melted. Because the ria was narrower near the sea, when the newly emerged bottom of the ria refroze a closed system resulted (Pissart and French, 1977). The latter thus dictated the appearance of a pingo almost $1,600 \mathrm{~m}$ in length, since jection occurred into the site of a stream channel which retarded the freezing process.

Svensson (1969) has described a pingo of the closed type from Svalbard. Âhman (1973) interprets it as resulting from the development of permafrost in recent sediments following the accumulation of the sediments and uplift of the land during postglacial time.

Enigmatic pingos. In addition, almost 140 pingos have been described from the sand and gravels of the Beaufort formation on the summit of Prince Patrick Island (Pissart, 1967). From their position in the topography an open system origin is inconceivable. Since these forms are arranged in two approximately parallel lines, $2 \mathrm{~km}$ apart, the hypothesis has been advanced that with the freezing of the Beaufort sands following the melting of an ice cap, pockets of unfrozen sediments were entrapped; structural control, in which faults played a role, is presumed to have dictated the size and shape of these unfrozen pockets.

Submarine pingos. Forms absolutely identical to the pingos east of the Mackenzie Delta have been identified (Shearer et al., 1971) on the bed of the Beaufort Sea 120 
$\mathrm{km}$ north of the Tuktoyaktuk Peninsula. 78 mounds were recorded within an area of $5,000 \mathrm{~km}^{2}$ at depths not exceeding $65 \mathrm{~m}$. The mean diameter of the mounds at their bases is $400 \mathrm{~m}$, while their mean height is $30 \mathrm{~m}$. Others have been found at a few locations outside the $5,000 \mathrm{~km}^{2}$ area, which demonstrates that they are numerous on the continental shelf of the Beaufort Sea. The origin of these mounds is still little known. It is not known whether they were submerged after they appeared, or whether they formed on the bed of the sea. In either case, a Mackenzie-type origin is involved, related to the freezing of former lake beds. However, both hypotheses run into objections. It is difficult to imagine that these pingos could have withstood erosion during the marine transgression. On the other hand, while the water temperature at the sea bed in September 1970 was generally below $-1^{\circ} \mathrm{C}$ (and in some places as low as $-1.8^{\circ} \mathrm{C}$, which is the lowest possible temperature, given the salinity of the water), it is logical to question whether with a temperature so minimally lower than $0^{\circ} \mathrm{C}$ freezing penetration would be rapid and significant enough to give rise to closed system pingos.

\section{Open system pingos}

With regard to open system pingos, we do not have available at present studies comparable to those which Mackay has pursued for several decades in the Mackenzie Delta area. As a result, these forms are much less well known.

The distinction between the two types of mounds is based on genetic considerations rather than morphological. Pingos almost as high as closed system pingos and identified as open system pingos have been observed. A form $42 \mathrm{~m}$ high has been described from Svalbard by Liest $\phi 1$ (1977); mounds $30 \mathrm{~m}$ high were observed by Müller (1959) in Greenland and by Holmes, Hopkins and Foster (1968) in Alaska. The genetic mechanism is in principle the same, i.e., that of water in the ground placed under pressure. As in the case of the closed system studied above, this exertion of pressure gives rise to the appearance of significant ground ice masses. However, in this case it is not cryostatic pressure which is involved but rather a simple hydrostatic phenomenon due to the pressure developed in an aquifer as a result of differences in elevation.

In the most common situation, i.e., that which exists in Siberia (Shumskii, 1959), central Alaska (Holmes, Hopkins and Foster, 1968) and the Yukon in Canada (Hughes, 1969), these forms occur in the discontinuous permafrost zone. Hence, as the diagram demonstrates, the water circulates mainly immediately beneath a relatively thin permafrost. Pewe (1975) believes that the location of the majority of the pingos observed in Alaska and the Yukon by the authors cited above, i.e., at the foot of south-facing slopes, may be explained by the fact that the water can penetrate into the ground more easily on an adret, rather than on an ubac slope.

These pingos generally occur at the foot of slopes near the contact with the valley bottom. They generally form on moderate slopes, for example slopes of between 2 and $26^{\circ}$ in the Yukon (Hughes, 1969). The uplifted materials consist of slope deposits, consisting of bedrock debris, eolian deposits or colluvium. The influence of fractures in the substrate has commonly been observed in the location of these pingos. 


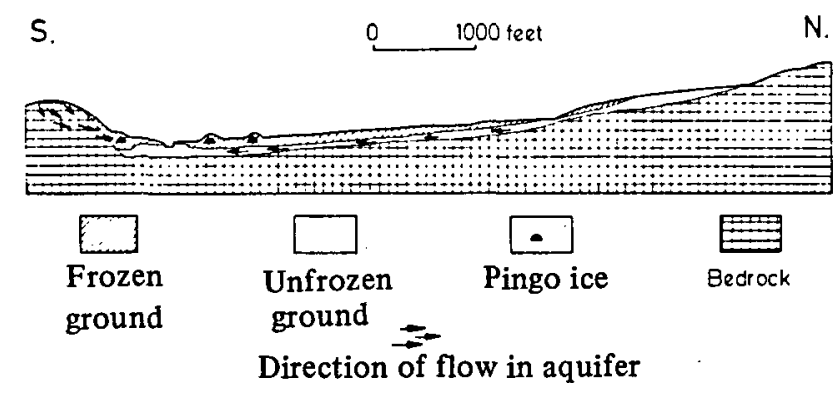

Fig. 3. Origin of open system or East Greenland type pingos, according to Holmes, Hopkins and Foster (1968).

These involve zones where water circulation is facilitated (Holmes, Hopkins and Foster, 1968). To my knowledge there has been no record of a pingo in the discontinuous permafrost zone in Alaska or the Yukon which has uplifted and deformed the bedrock.

These pingos are commonly very widely scattered. However, in Alaska their density may in places attain 10 per $260 \mathrm{~km}^{2}$ (10 per $100 \mathrm{sq}$. miles). They are very rare in areas which have been glaciated within the past 25,000 years (Pewe, 1975). The reason for this is still uncertain. Hughes (1969) sees in this the effect of the reworking of superficial deposits by the glacier, or else the different characteristics of the permafrost associated with the development of the glacier.

From Greenland and Svalbard pingos have been described in areas which appear to possess continuous permafrost. Proof of the presence of continuous permafrost is sometimes difficult. The assemblage of data collected by Liest $\phi 1$ (1977) from Svalbard demonstrates variations in permafrost thickness ranging from 75 . to $450 \mathrm{~m}$ in the region of Svalbard from which he described almost 70 pingos. In northeastern Greenland, Cruickshank and Colhoun (1965) mentioned variations in permafrost thickness ranging from 80 to $220 \mathrm{~m}$ in a region where they describe 5 typical pingos; they state that they are located in a region of continuous permafrost. Müller (1959), in similar fashion, considered that the pingos of East Greenland had formed in a continuous permafrost zone.

In Greenland (Müller, 1959; Cruickshank and Colhoun, 1965), Svalbard ( $\AA$ hman, 1973) and Siberia (Shumskii, 1959), there exist forms which have developed by updoming the bedrock. This type of pingo may be related to secondary faults, as O'Brien (1971) has suggested from Greenland. However, the majority of these forms have developed in spreads of unconsolidated materials, namely slope deposits, fluvial deposits or marine terraces. What appear to be perennial springs have commonly been observed in association with pingos, both in Alaska (discontinuous permafrost) (Holmes, Hopkins and Foster, 1968) and in Greenland (continuous permafrost) 
(Müller, 1959). They may give rise to groups of pingos, with some mounds appearing on the flanks of others: Müller (1959) has published an excellent photo of this situation. Very probably when the spring was stopped up by the pingo the flow of water was diverted to the side, forming another pingo close to the first. These outflows of water produce naledi (icings) in winter; these have been observed and well described from Spitzbergen (Akerman, 1980; Liest $\phi 1,1977$ ). They had earlier been reported by Müller (1959) from Greenland.

These outflows of water suggest that certain of the forms are still in the process of developing at present. Moreover, examination of their morphology would indicate that a certain number of these mounds are completely formed, whether they be in Alaska, Svalbard or Greenland (Holmes, Hopkins and Foster, 1969; Åhman, 1973; O’Brien, 1971).

Several authors have raised the question of how much pressure is required to raise the ground. Muller (1959) calculated that to raise the ground the pressure did not need to exceed 3 or 4 atmospheres; but to dome up frozen ground, greater pressure is necessary, possibly exceeding 10 atmospheres or so. Muller estimated the total pressure required to lie between 2.5 and 18 atmospheres. Holmes, Hopkins and Foster (1969) for their part made reference to 6 to 22 atmospheres. Since in some cases the relief did not appear to be sufficient to provide the necessary pressure, Holmes, Hopkins and Foster (1969) wondered whether in some cases cryostatic pressure augmented the hydrostatic pressure to give rise to the pingos which they were studying.

To my knowledge, the existence of high pressure beneath an open system pingo has been demonstrated only in the case of a pingo $18 \mathrm{~m}$ high and still growing (at 20 $\mathrm{cm} /$ year), located on the Qinchai-Xizang plateau in China (Shijiu, 1980). Situated in a region where the author believes there to be continuous permafrost (although the mean annual temperature is only $-4^{\circ} \mathrm{C}$, personal communication), the pingo was investigated by means of drilling. After the drill had passed through $14 \mathrm{~m}$ of ice, a gusher of water, gas and mud shot up to a height of $22 \mathrm{~m}$. Unfortunately we possess very few details on this study, although the author does report that the pingos are located at a site where faults cross. The height of nearby summits (at 4,650 m) exceeds that of the site of the pingo by $500 \mathrm{~m}$.

The type of ice forming these open system pingos has rarely been described. O'Brien (1971) observed large ice crystals in a Greenland example, which he considered to be typical injection ice. Apparently there is no reason to believe that the nature of the ice is different from that in closed system forms.

Thus open system pingos are associated with the circulation of water under pressure, beneath or within the permafrost. The conditions of this water circulation depend on the nature and the disposition of the unconsolidated deposits, the jointing of the bedrock and also the local characteristics of the permafrost. These highly variable factors mean that as Holmes, Hopkins and Foster (1969) have indicated, the mechanism of formation of these pingos is still very poorly understood. 
Another type of form, of very similar origin has recently been described from China, from the Wuli Mountains and from the foot of the Tanggula Mountains (Zhiju, 1979). These involve what appear to be closed system mounds which may reach heights of $3 \mathrm{~m}$. These mounds literally explode in late June or July. Mud and water are shot into the air to heights of 10 to $15 \mathrm{~m}$ over a radius of $10 \mathrm{~m}$. This phenomenon is explained by the existence in the cores of the mounds of significant quantities of gas (probably $\mathrm{CO}^{2}$ ). The explosion produces a deep crater on the site of the phenomenon. The author proposes calling this type of form a "Mount Wuli pingo." Since they persist for only a few months, these forms do not appear to merit the name pingo. They would be more felicitously termed "Mount Wuli seasonal mounds."

\section{PALSAS}

\section{Introduction}

There exist mounds other than pingos, whose uplift is also due to the formation of ground ice masses which persist for many years. These forms are known as palsas and in general are not easily confused with pingos. Since the distinction between them and pingos lies essentially in the mechanism which gives rise to them, we will begin by discussing the mode of formation of these mounds.

\section{Mechanism of formation}

All authors are in agreement that palsas are mounds which form following the formation of segregation ice in the ground. This ice develops through cryosuction, without the water being subjected to pressure as in the case of the mechanism which produces pingos. Moreover typical palsas coincide with islands of permafrost. No controversy has emerged in the literature concerning the genesis of these forms, at least not since the origin of segregation ice has been recognized, following Taher's studies around 1930. Previously their origin had been unexplained.

\section{Seasonal mounds}

In this review article it seems necessary to say a few words about seasonal mounds, in that they strongly resemble pingos, although they are generally much less than $3 \mathrm{~m}$ in height. The forms in question are mounds formed by the development of a mass of ice within the active layer. Hence these mounds are destined to disappear during the summer following their formation, or if melting is not complete during the first year, then during succeeding summers.

According to Shumskii (1959) these mounds, like pingos, may develop through freezing of water in a closed system within the active layer, or by the buildup of pressure in an aquifer feeding the active layer. In view of their ephemeral duration these forms are not considered to be pingos. Porsild (1938) described and photographed a seasonal mound on the site of a spring where a pingo subsequently grew (Mackay, 1979). The seasonal mound developed from the injection of water into the active layer, but apparently it persisted for only 2 or 3 years. 


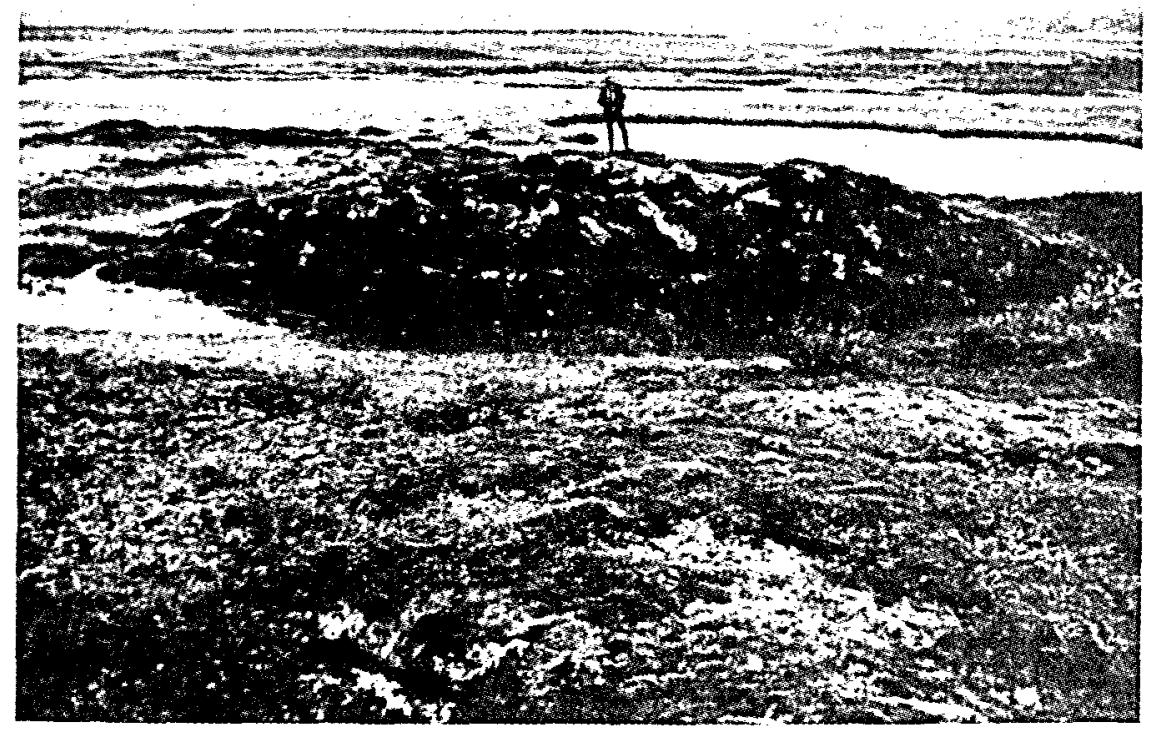

Fig. 4. Dome-shaped palsa near Kevo in Finnish Lapland.

\section{Description of palsas}

The morphology of palsas is even more varied than that of pingos. Wrammer (1967), Schunke (1973) and Åmman (1977) have produced classifications which all resemble each other fairly closely. I shall reproduce below that of the last author cited; it combines form and internal structure in the description. This work of Ahman (1977) was based on palsas in northern Norway; however, his classification appears to be applicable on a global scale. He distinguished 5 types of palsas (p. 5), namely:

Dome-shaped palsas. These bear an external resemblance to pingos. They present a circular or oval shape in plan. They may exceptionally attain a height of $10 \mathrm{~m}$ above the surrounding surface. These forms generally appear in locations where there are considerable thicknesses of peat, commonly exceeding $3 \mathrm{~m}$. Segregation ice forms in the peat. When it forms in the underlying mineral materials the shape of the mound is modified, becoming more complex.

Esker-shaped palsas. These appear as long ridges 2 to $6 \mathrm{~m}$ high and 50 to $500 \mathrm{~m}$ long. The long axis is aligned parallel to the slope. In the most typical forms segregation ice develops in the underlying mineral material.

String palsas. Their height does not exceed $2 \mathrm{~m}$; their length varies between 25 and $100 \mathrm{~m}$. They appear as parallel ridges aligned at right angles to the slope. A tran- 
sition has been observed between this type of form and string bogs. The forms are generally composed of peat but where the latter material is not deep enough, the min. eral soil contributes to the relief of the feature.

Palsa plateaux. They generally do not exceed $1.5 \mathrm{~m}$ in height. They commonly cover an area of 1,000 to $50,000 \mathrm{~m}^{2}$ but may attain an area of $1 \mathrm{~km}^{2}$. The surface of the palsa is slightly undulating and commonly displays some water-filled thermokarst depressions. The side slopes of these palsas are steep. The peat covering them is only 50 to $75 \mathrm{~cm}$ deep. The segregation ice has accumulated in the underlying mineral material.

Complex palsas. These assume a very complicated shape and cover significant areas. Individual forms are difficult to identify. Eroding and disintegrating forms are juxtaposed with growing forms. In general the segregation ice is developed in the mineral material.

\section{Mineral and organic palsas}

All these palsas are associated with peat bogs. Hence many authors consider that the peat cover constitutes one of the fundamental characteristics of palsas (Lundquist, 1965; Friedmann, et al., 1971; Seppala, 1972). The latter author even proposes distinguishing between pingos and palsas solely on the basis of this criterion. Since 1910 the term "palsa" in the scientific literature has applied to forms consisting solely of peat ( $\AA$ hman, 1977). However, it is now clearly established that many palsas result from an accumulation of ice in the mineral soil beneath the peat. In certain cases the layer of peat may be very thin, or even absent. Friedman et al. (1971) have described a section from Iceland, revealing only $25 \mathrm{~cm}$ of peat on the summit and $15 \mathrm{~cm}$ on the sides. Seppala (1980) studied a palsa in British Columbia which was covered by only $7 \mathrm{~cm}$ of peat. Wrammer (1967) has described true mineral palsas without any surficial peat from Lapland. Moreover the existence of such forms had earlier been suspected, particularly following the work of Svensson (1964). Similar forms were also described by Lagarec from Quebec in 1973. Hence Ahman (1977) has proposed that the term palsa be applied to a mound caused by the formation of segregation ice in the ground without there necessarily being any peat on its surface. In the latter case the forms would be purely mineral palsas. It was under this heading of "mineral palsas" as distinct from "organic palsas" that Dionne (1968) described numerous forms from the James Bay area of subarctic Quebec, demonstrating that they were identical with the cryogenic mineral mounds reported by various authors (Payette et al., 1976; Payette and Seguin, 1979; Lagarec, 1978). These Canadian studies, which describe and illustrate a wide variety of forms, are at present the most important works on the subject. I believe that many of the fossil forms which at present are thought to be traces of pingos are in fact traces of mineral palsas. This is certainly the case with regard to the "viviers" of the Hautes Fagnes in Belgium, which are evidence of the formation during the late Dryas of dome-shaped, esker-shaped and complex mineral palsas (Pissart, 1974; Pissart and Juvigne, 1981). 


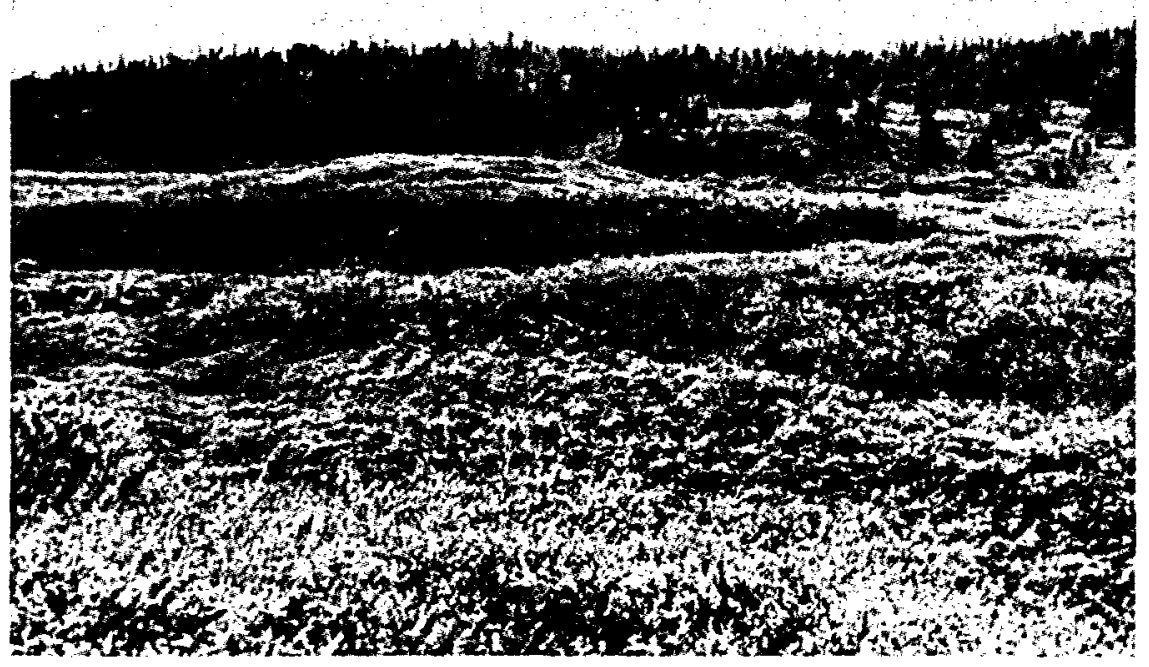

Fig. 5. Mineral palsa in the valley of the Aveneau, $30 \mathrm{~km}$ east of Fort Chimo, Canada.

\section{Climate and permafrost as related to palsas}

Wherever they have been observed palsas are at the limit of permafrost, i.e., in regions where the mean annual temperature lies between $-1^{\circ}$ and $-5^{\circ} \mathrm{C}$. The following are some mean annual temperatures which have been cited in association with palsas: -2 to $-3^{\circ} \mathrm{C}$, Norway, Ahman (1967); -1 to $-4^{\circ} \mathrm{C}$ for wooded palsas and -4 to $-4.5^{\circ} \mathrm{C}$ for the main zone of non-wooded palsas, James Bay area, Quebec, Dionne (1978);-1.2 to $-1.9^{\circ} \mathrm{C}$, Iceland, Friedman et al. (1971); $\cdot 5^{\circ} \mathrm{C}$, Quebec, Hamelin and Cailleux (1969); $-4.5^{\circ} \mathrm{C}$, Quebec, Heim (1976); -2 to $-3^{\circ} \mathrm{C}$, British Columbia, Seppala (1980); $-1.2^{\circ} \mathrm{C}$, Manitoba, Zoltai and Tarnocai (1971). Payette et al. (1976) have reported that the range of mineral palsas extends farther north than that of organic palsas. Hence these forms invariably coincide with the zone of discontinuous permafrost; indeed they commonly represent the most southerly islands of permafrost. They indicate the existence of local, sporadic permafrost (Dionne, 1978). Permafrost exists only beneath the palsa; it is totally absent from the surrounding area.

The thickness of the permafrost beneath a palsa has rarely been observed. Zoltai and Tarnocai (1971) have described a zone of frozen ground of the order of $5.5 \mathrm{~m}$ thick beneath a wooded palsa $1.5 \mathrm{~m}$ high. Evseev (1973) has indicated that in the USSR the thickness of the permafrost is a function of the height of the palsa. It generally attains depths of 6 to $8 \mathrm{~m}$ for palsas 1 to $2 \mathrm{~m}$ high, 10 to $12 \mathrm{~m}$ for palsas 2 to 4 $\mathrm{m}$ high, and 15 to $20 \mathrm{~m}$ for palsas 8 to $10 \mathrm{~m}$ high. However, variations do occur de- 
pending on the mean temperature. Thus Evseev reports that, in the European part of the USSR in the case of a palsa $3.5 \mathrm{~m}$ high, the depth of the permafrost is $11 \mathrm{~m}$ at the southern limit of the zone of palsa occurrence, and $16 \mathrm{~m}$ at the northern limit.

The depth of the active layer on palsas is variable; 30 to $60 \mathrm{~cm}$ and 60 to $95 \mathrm{~cm}$ respectively for the regions studied by Schunke (1973) and Friedman et al. (1971) in Iceland; 43 to $127 \mathrm{~cm}$ on a wooded palsa studied by Zoltai and Tarnocai (1971) in Manitoba. Seppala (1976), who recorded the temperature in the core of a palsa throughout a summer, has demonstrated that thaw depth is greater on the south-facing slope.

\section{Type of ice}

The segregation ice observed within palsas appears principally in the form of horizontal lenses. In the upper part of the section horizontal and vertical veins give the ground a typical brecciated appearance (Svensson, 1964; Åhman, 1977). The ice lenses may be very thick, e.g., $15 \mathrm{~cm}$ (Seppala, 1980), $10 \mathrm{~cm}$ (Zoltai and Tarnocai, 1971). The amount of water they contain is clearly very considerable. It may reach 178 percent by weight of a sample extracted from the core of a palsa mound ( $\AA$ hman, 1977).

In order for palsas to form, the first prerequisite is the presence of a material favorable to the formation of segregation ice. For this reason silts represent a preferred material in terms of the development of these forms. Ahman (1977) has cited silt and clay contents of 19 to 50 percent in the case of palsa plateaux. In the case of complex palsas the same values lie between 57 and 86 percent. These data derive from analyses performed at four different sites in Lapland.

Table 1, referred to earlier, presents values for pressure $\left(\mathrm{kg} / \mathrm{cm}^{2}\right)$ which limit the growth of segregation ice at the ice/water interface where the growth of the ice lens occurs, as based on laboratory experiments. Assuming one knows the density of the overlying formations, it is possible to deduce from this table the depth to which segregation ice may appear. Assuming a mean density of 1.5 , that depth would be $0.5 \mathrm{~m}$ in medium and fine-grained sands, $1 \mathrm{~m}$ in medium silts, $3.3 \mathrm{~m}$ in fine silts, $13 \mathrm{~m}$ in silty clays, and even greater depths in clays. Since this segregation ice forms at a certain depth, it is clear that palsas can practically never exceed a height of $10 \mathrm{~m}$.

With regard to this calculation one should also add that the density of the uplifted material plays a major role in determining the height of the mounds. In light peat growth is much easier since the overlying pressure is less.

A sufficient moisture content is also indispensable in permitting the growth of the ice lenses. Moreover, it is essential that the ground not thaw in summer, and hence that the amount of heat which penetrates in summer is less than that which escapes in winter. The insulating role played by the peat, especially in summer has been invoked by Åmman (1977) and by Zoltai and Tarnocai (1971). Dry peat is in fact a good insulator during the warm season. In winter when it is frozen and contains a certain quan- 
tity of ice, its thermal conductivity increases considerably. The snow cover plays a very important role (Svensson, 1961). The summits of palsas are generally blown clear of snow by the wind ( $\AA$ hman, 1977). If not completely clear of snow, the accumulation is commonly less on the summits (Payette and Lagarec, 1972). Hence the frost penetrates more easily during the winter (Brown, 1970) and surficial drying proceeds more rapidly during the summer (Lindqvist and Mattson, 1965). In the case of wooded palsas described by Zoltai (1970) and by Zoltai and Tarnocai (1971), wind action is of necessity very limited. Indeed these authors mention that towards their southern limit palsas may support dense stands of black spruce and, less commonly, willow. This tree cover has a very great effect on the depth of the active layer; in the forest it decreases mainly in relation to decreasing snow depth (Zoltai and Tarnocai, 1971).

\section{Surface aspect}

The surfaces of palsas generally reveal a network of yawning fissures which extend down through the active layer and in some cases even penetrate to 10 to $20 \mathrm{~cm}$ into the permafrost (Åhman, 1977). According to Svensson (1961), these fissures may possibly result either from tension caused by the growth of the mound, or from desiccation effects caused by the drying of the peat uplifted by the palsa, or finally from the effect of thermal contraction in winter when the wind has removed the snow. Ahman (1977) believes that the fissures penetrating the permafrost are due to this latter phenomenon.

According to Seppala (1976), these cracks do not appear to encourage more rapid thawing in their vicinity, since the cold air accumulates and persists in them over the summer. On the other hand, since rain water can penetrate more easily into the ground via these cracks, it encourages melting.

\section{Thawing forms}

Many palsas are undergoing processes of erosion and thawing which result mainly from thermokarst phenomena. Even during their growth palsas are commonly surrounded by a circular flooded depression. It is suggested ( $\$$ hman, 1977) that this is due to subsidence of the peat due to the weight of the growing palsa. Subsequently this pond expands by thermal erosion into the heart of the palsa itself (Svensson, 1961; Wrammer, 1967; Hamelin and Cailleux, 1969), attacking it laterally and provoking the collapse of the covering material. This thus involves a true cycle in the evolution of palsas. Mackay (1978) has emphasized the basic difference between pingos and palsas during the process of melting: destruction from the center with a volcano-like shape in the case of pingos; lateral collapse in the case of palsas. This evolution seems to be quite commonly verified in the case of organic palsas. By contrast various observations (Lagarec, 1973; Dionne, 1978; Pissart and Gangloff, in preparation) indicate that in the case of mineral palsas, melting may take place from the summit.

Independently of this regime of growth followed by melting, which is unaffected by climate, a climatic warming is clearly likely to provoke the degradation of numer- 
ous palsas within an area. Having studied the mean temperatures in Lapland, Åhman (1977) has suggested that the numerous forms in a state of degeneration derive from the rise in the mean temperature which occurred from 1931 to 1960 . The temperature decrease observed between 1960 and 1974 was thought to be responsible for the existence of numerous embryonic forms.

While the majority of authors interpret palsas as forms which result directly from local uplift of the ground, some authors, especially Schunke (1973) have described fields of palsas from Iceland which they believe are due to degradation due to melting of a surface which has been heaved up by freezing. Various authors, including Jahn (1976), Lagarec (1976) and Payette et al. (1976) confirm that these two types of palsas do exist.

\section{Dating}

Palsas may, however, be extremely old. On the basid of $\mathrm{C}^{14}$ dates Åmman (1977) estimates that two forms studied in Lapland began to form 750 years ago in one case, and 2,450 years ago in the other. Heim (1976) proposed an age of 4,900 years for a palsa which he studied in Nouveau Quebec. Dates such as these should be interpreted with caution, since they establish simply when the peat ceased to accumulate.

\section{CONCLUSION}

The distinction between the different types of periglacial mounds which we have been studying must be based on the mechanisms which give rise to them.

In the light of this statement, and following a proposal advanced by Wrammer in 1972, the term "pingo" should be restricted to perennial mounds (formed of segregation or injection ice) which have formed following the exertion of pressure on ground water. If the pressure is exerted due to the process of freezing, the pingos are those resulting from cryostatic pressure, and are known at present as closed system pingos or Mackenzie type pingos. Water placed under pressure due to the force of gravity in an area of high relief produces pingos resulting from hydraulic pressure; in the literature they are known as open system pingos or Greenland type pingos.

The term "palsa" should be reserved for all perennial mounds resulting from cryosuction, without any pressure being applied to the aquifer. Commonly very complex in shape, these mounds generally appear in peat bogs (organic palsas); however, they may also exist independently of any peat cover and in that case merit the name mineral palsas.

The term "pingo" is used to describe a mound which is clearly demarcated at first glance. The term "palsa" by contrast may be applied to a mound which is much less apparent in the landscape when the form involved is more extensive (palsa Platea). However palsas are always bounded by a clearly demarcated steep front, which is well marked in the topography. If one specifies that such a clear-cut steep front is an essential component of a palsa, there is no longer any risk of confusing palsas with a surface which has been heaved up by segregation ice. 
As mentioned earlier, several authors have proposed that a peat cover be considered as the characteristic distinguishing palsas from pingos. From the genetic point of view this proposal would signify that the poor thermal conductivity of the uplifted peat is the essential feature of these forms. Without wishing to diminish the importance of this phenomenon, one should however note that several objections may be formulated against this proposal: 1) some typical pingos are covered with peat (see Mackay, 1979, Fig. 29, p. 20); 2) there exists every kind of transitional form between organic and mineral palsas; 3 ) mounds which have appeared beneath peat in the zone of deep, continuous permafrost should be considered as palsas (forms described by A.L. Washburn at the Fourth International Permafrost Conference in 1983).

Palsas are located within the discontinuous permafrost zone. Pingos resulting from hydraulic pressure also exist in the same zone; others occur in the continuous permafrost zone. Pingos resulting from cryostatic pressure require deep permafrost, corresponding to a mean temperature lower than that necessary for the preceding forms.

Scars of periglacial mounds which one can find particularly on the plateau of the Hautes Fagnes in Belgium (Pissart and Juvigne, 1981) and in Wales (Pissart, 1963) are incontestably the fossil scars of well-developed mineral palsas, the equivalent of which may currently be found in Northern Quebec (Pissart and Gangloff, 1984). It would be wrong nowadays to identify every depression surrounded by a rampart as the fossil scar of a pingo. They can in fact also result from the melting of mineral palsas.

\section{Literature}

Ahman, R. "Pingos in Adventdalen and Reindalen, Spitsbergen," Svensk Geografisk Arsbok, Vol. 49, 1973, pp. 190-197.

"The structure and morphology of minerogenic palsas in Northern Norway," Biuletyn Peryglacjalny, Vol. 26, 1976, pp. 25.31.

"Palsas in northern Norway," Meddelanden fron Lunds Universitets Geografiska Institutionen Avhandlingar, No. 78, $165 \mathrm{pp}$.

Akerman, J. "Studies on periglacial geomorphology in West Spitsbergen," Meddelanden fron Lunds Universitets, 1980, $297 \mathrm{pp}$.

Balkwill, H.R., K.J. Roy, W.S. Hopkins and W.V. Sliter. "Glacial features and pingos, Amund Ringnes Island, Arctic Archipelago," Canadian Journal of Earth Sciences, Vol. 11, 1974, pp. 1319.1325.

Barr, W. and M. Syroteuk. "The pingos of the Tuktoyaktuk area: a review," The Musk-Ox, No. 12, 1973, pp. 3-12.

Brown, R.J.E. "Occurrence of permafrost in Canadian peatlands," Proceedings of the Third International Peat Congress, Quebec, Canada, National Research Council of Canada Research Paper, No. 432, 1970, pp. 174-181.

"Ground ice as an initiator of land forms in permafrost regions," National Research Council of Canada Division of Building Research Technical Paper, No. 431, 1973, pp. 2542.

and W.O. Kupsch. "Permafrost terminology," National Research Council of Canada Technical Memoir, No. 111, 1979,66 pp. 
Burns, JJ. "Pingos in the Yukon-Kuskokwim delta, Alaska: their plant succession and their use by mink," Arctic, Vol. 17, 1964, pp. 203-210.

Cruickshank, J.G. and E.A. Colhoun. "Observations on pingos and other landforms in Schuchterdal, Northeast Greenland," Geografiska Annaler, Vol. 47A, 1965, pp. 224-236.

Cui, Z. "Preliminary study on some characteristic features of periglacial phenomena on Qinghai-Xizang Plateau," Tongbao, Vol. 25, No. 8, 1980, pp. 700-705.

Dionne, J.C. "Periglacial forms and phenomena in the James Bay area, subarctic Quebec," Géographie physique et Quaternaire, Vol. 32, No. 3, 1978, pp. 187-247.

Everett, D.H. "The thermodynamics of frost damage to porous solids," Transactions of the Faraday Society, Vol. 57, No. 465, Part 9, 1961, pp. 1541-1551.

Evseev, V.P. "Migrational frost mounds," in: Permafrost, Second International Conference, USSR contribution. Washington: National Academy of Sciences, 1978, pp. 121-123.

Flemal, R.C., K.C. Hinley and J.L. Hesler. "Fossil pingo field in North-central Illinois," Geological Society of America Memoir, No. 136, 1969.

Flemal, R.C. "Pingos and pingo scars: their characteristics, distribution and utility in reconstructing former permafrost environments," Quaternary Research, Vol. 6, 1976, pp. 37-53.

Forsgren, B. "Studies of palsas in Finland, Norway and Sweden, 1964-1966," Biuletyn Peryglacjalny, Vol. 17, 1968, pp. 117.123.

Fraser, J.K. "Physiographic notes on features in the Mackenzie delta area," The Canadian Geographer, No. 8, 1956, pp. 18-23.

French, H.M. "Ice cored mounds and patterned ground, southern Banks Island, Western Canadian Arctic," Geografiska Annaler, Vol. 53A, 1971, pp. 32-38.

The Periglacial environment. London and New York: Longmans, 1976, $309 \mathrm{pp}$.

and L. Dutkiewicz. Pingos and pingo-like forms, Banks Island, Western Canadian Arctic," Biuletyn Periglacjalny, Vol. 26, 1976, pp. 211-222.

Friedman, J.D., C.E. Johansson, N. Oskarsson, H. Svensson, S. Thorarinsson and R.S. Williams Jr. "Observations on Icelandic polygon surfaces and palsa areas. Photo interpretation and field studies," Geografiska Annaler, Vol. 53A, 1971, pp. 115-145.

Gell, A. "Fabrics of icing-mound and pingo ice in permafrost," Journal of Glaciology, Vol. 20, No. 84, 1978, pp. 563-569.

Gorbunov, A.P. "The periglacial region of the Tyan Shan," Biuletyn Peryglacjalny, Vol. 19, 1969, pp. 151-174.

Hamelin, L.E. and A. Cailleux. "Palsas in the basin of the Grande Riviere de la Baleine," Revue de géographie de Montréal, Vol. 23, No. 3, 1969, pp. 329-337.

Heim, J. "Palynological study of a palsa in the Richmond area, Nouveau-Quebec, Canada," Cahiers de géographie du Québec, Vol. 20, 1976, pp. 221-238.

Holmes, G.W., D.M. Hopkins and H.L. Foster. "Pingos in central Alaska," United States Geological Survey Bulletin, No. 1241H, 1968, 40 pp.

Hughes, O.L. "Distribution of open system pingos in Central Yukon Territory with respect to glacial limits," Geological Survey of Canada Paper, No. 69-34, 1969, $8 \mathrm{pp}$.

Hussey, K.M. and R.W. Michelson. "Tundra relief features near Point Barrow, Alaska," Arctic, Vol. 19, 1966, pp. 162-183. 
Jahn, A. Problems of the periglacial zone. Washington: National Science Foundation, $1975,223 \mathrm{pp}$.

Johnston, G.H. and R.J.E. Brown. "Effect of a lake on distribution of permafrost in the Mackenzie River delta," Nature, Vol. 192, 1961, pp. 251-252.

Judge, A.S., A.E. Taylor and M. Burgess. "Canadian geothermal data collection, northern wells, 1977-1978," Earth Physics Branch, Geothermal Series, No. 11, Ottawa: Department of Energy Mines and Resources, 1979, 187 pp.

Krinsley, D.B. "Birch Creek pingo, Alaska," United States Geological Survey Professional Paper, No. 525C, 1965, pp. C133-C136.

Lagarec, D. "Elements of the cryogenic morphology of Richmond Gulf, NouveauQuebec," Cahiers de géographie du|Québec, Vol. 17, No. 42, 1973, pp. 465-482.

"A geomorphological study of palsas in the Chimo region, Nouveau-Quebec, Canada," Cahiers de gkologie, No. 92, 1976, pp. 153-163.

Leffingwell, E. "The Canning River region, Northern Alaska," United States Geological Survey Professional Paper, No. 109, 1919, 251 pp.

Liest $\phi 1,0$. "Pingos, springs and permafrost in Spitsbergen," Norsk Polarinstitutt Arbok 1975, Oslo, 1977, pp. 7-29.

Lindqvist, S. and J.O. Mattsson. "Studies on the thermal structure of a palsa," Svensk Geografisk Arsbok, Vol. 40, 1965, pp. 38-49.

Lundquist, J. "Earth and ice mounds: a terminological discussion," in: The periglacial environment, T.L. Péwé, ed. Montreal: McGill-Queen's University Press, 1969, pp. 203-215.

Maarleveld, J.C. "Frost mounds. A summary of the literature of the past decade," Mededelingen van de Geologische Stichting, Nieuwe Serie, Vol. 17, 1965, pp. 3-16.

Mackay, J.R. "Pingos of the Pleistocene Mackenzie River delta area," Geographical Bulletin, Vol. 18, 1962, pp. 21-63.

"The Mackenzie Delta area, N.W.T.," Geographical Branch Memoir, No. 8, $1963,202 \mathrm{pp}$.

"Gas-domed mounds in permafrost, Kendall Island, N.W.T.," Geographical Bulletin, Vol. 7, 1965, pp. 105-115.

"Some observations on the growth of pingos," in: Mackenzie Delta area monograph, D.E. Kerfoot, ed. St. Catharines, Ontario: Brock University, 1972, pp. 141-148.

"Some aspects of permafrost growth," Geological Survey of Canada Paper, No. 73-1A, pp. 141-148.

" "The growth of pingos, Western Arctic coast, Canada," Canadian Journal of Earth Sciences, Vol. 10, 1973, pp. 979-1004.

"Problems in the origin of massive icy beds, Western Arctic, Canada," in: Permafrost, Second International Conference, North American contribution. Washington: National Academy of Sciences, 1973, pp. 223-227.

"The age of Ibyuk pingo, Tuktoyaktuk Peninsula, District of Mackenzie," Geological Survey of Canada Paper, No. 76-1 B, 1976, pp. 59-60.

"Pulsating pingos, Tuktoyaktuk Peninsula, N.W.T.," Canadian Journal of Earth Sciences, Vol. 14, No. 2, 1977, pp. 209-222.

"Sub-pingo water lenses, Tuktoyaktuk Peninsula, N.W.T.," Canadian Journal of Earth Sciences, Vol. 15, No. 8, 1978, pp. 1219-1227. 
"Pingos of the Tuktoyaktuk Peninsula area, Northwest Territories," Géographie physique et Quaternaire, Vol. 33, No. 1, 1979, pp. 3-61.

and J.K. Stager. "The structure of some pingos in the Mackenzie Delta area, N.W.T., " Geographical Bulletin, No. 4, 1966, pp. 360-368.

and R.F. Black. "Origin, composition and structure of perennially frozen ground and ground ice: a review," in: Permafrost, Second International Conference, North American contribution. Washington: National Academy of Sciences, 1973, pp. 185-192.

Müller, F. "Observations on pingos," Meddelelser om Grфnland, Vol. 153, No. 3, 1959, 127 pp. (English translation: National Research Council of Canada, Division of Building Research, Technical Translation, No. 1073, 1963, 117 pp.).

O'Brien, R. “Observations on pingos and permafrost hydrology in Schuchert Dal, N.E. Greenland," Meddelelser om Gr申nland, Vol. 195, No. 1, 1971, 20 pp.

Payette, S. and D. Lagarec. "Observations on snow conditions at Poste-de-la-Baleine, Nouveau-Quebec, winter 1972," Cahiers de géographie du Québec, Vol. 16, No. 39, 1972, pp. 469-481.

Payette, S. and M.K. Seguin. "Cryogenic mineral mounds in the lowlands of the Riviére aux Feuilles, Nouveau-Québec," Géographie physique et Quaternaire, Vol. 33, No. 34, 1979, pp. 339-357.

Payette, S., H. Samson and D. Lagarec. "The evolution of permafrost in the taiga and in the forest tundra, western Quebec-Labrador Peninsula," Canadian Joumal of Forestry Research, Vol.6, No. 2, 1976, pp. 203-220.

Péwe, T.L. "Quaternary geology of Alaska," United States Geological Survey Professional Paper, No. 835, 1975, 145 pp.

Pissart, A. "Traces of pingos in Wales (Great Britain) and on the Hautes Fagnes plateau (Belgium)," Zeitschrift fur Geomorphologie, Vol. 7, 1963, pp. 147-165.

"The pingos of Prince Patrick Island $\left(76^{\circ} \mathrm{N}, 120^{\circ} \mathrm{W}\right), "$ Geographical Bulletin, Vol. 9, 1967, pp. 189-217.

"The viviers of the Hautes Fagnes are traces of periglacial mounds. But are they really pingos?" Annales de la Société Geologique de Belge, Vol. 97, 1974, pp. 359-381.

and H.M. French. "Pingo investigations, north-central Banks Island, Canadian Arctic," Canadian Joumal of Earth Sciences, Vol. 13, No. 7, 1976, pp. 937. 946.

and H.M. French. "The origin of pingos in regions of thick permafrost, Western Canadian Arctic," Quaestiones Geographicae, Vol. 4, 1977, pp. 149-159.

and E. Juvigne. "Genesis and age of the scar of a periglacial mound (pingo or palsa) in the Konnerzvenn, Hautes Fagnes, Belgium," Annales de la Societé Géologique de Belge, Vol. 103, 1981, pp. 73-86.

Porsild, A.E. Reindeer grazing in Northwest Canada. Ottawa: Department of the Interior, Yukon and NWT Branch, 1929, 46 pp.

"Earth mounds in unglaciated Arctic Northwestern America," Geographical Review, Vol. 28, 1938, pp. 46-58.

Rampton, V.N. and J.R. Mackay. "Massive ice and icy sediments throughout the Tuktoyaktuk Peninsula, Richards Island and nearby areas, District of Mackenzie," Geological Survey of Canada Paper, No. 71-21, 1971, 16 pp.

Rotnicki, K. and A. Babinski. "Cryogenic relief in the Bayan-Nuurin-Khotnor basin," 
Bulletin de l"Academie polonaise des Sciences de la Terre, Vol. 15, No. 3.4, 1977 , pp. 141-148.

Salmi, M. "Investigations on palsas in Finnish Lapland," in Ecologie des regions subarctiques [Ecology of the subarctic regions]. Paris, 1970, pp. 143-153.

Schunke, E. "Palsas and thermokarst in Central Iceland," Akademie der Wissenschaften, Göttingen, Nachrichten. II Math. Kl. Vol. 4, 1973, pp. 65-102.

Seguin, M.K. and J. Crepault. "Geophysical study of a field of palsas at Poste-de-laBaleine, Nouveau-Québec," Geographie physique et Quaternaire, Vol. 33, No. 3-4, 1979, pp. 327-337.

Seppala, M. "Seasonál thawing of a palsa at Enontekio, Finnish Lappland in 1974," Biuletyn Peryglacjalny, Vol. 26, 1976, pp. 17-24. p. 263.

"The term 'palsa'," Zeitschrift für Geomorphologie, Vol. 16, No. 4, 1972,

"Pingo-like remnants in the Peltojärvi area of Finnish Lappland," Geografiska Annaler, Vol. 54A, No. 1, 1972, pp. 38-45. 273-274.

"Stratigraphy of a silt-cored palsa, Atlin region, British Columbia, Canada," Arctic, Vol. 33, No. 2, 1980, pp. 357-365.

Shearer, J.M., R.F. MacNab, B.R. Pelletier and T.B. Smith. "Submarine pingos in the Beaufort Sea," Science, Vol. 74, No. 4011, 1971, pp. 816-818.

Shumskii, P.A. Principles of geocryology (permafrost studies). Part I. General cryology. Ottawa: National Research Council Technical Translation No. 1130, 1964.

Soloviev, P.A. "The bulgunniyakhi of Central Yakutiya," in: Permafrost studies in the Yakutsk Republic. Moscow: Izdatel'stvo AN SSSR, pp. 227-258.

Sparks, B.W., R.B.G. Williams and F.G. Bell. "Pingos in Great Britain," Proceedings of the Royal Society A, Vol. 327, 1972, pp. 329-343.

Stager, J.K. "Progress report on the analysis of the characteristics and distribution of pingos east of the Mackenzie Delta," Canadian Geographer, Vol. 7, 1956, pp. 13 . 20.

Svensson, H. "Frozen ground morphology of northeasternmost Norway," in: Ecology of the subarctic regions (Proceedings of the Helsinki Symposium), 1978, pp. 161168.

"Nagra iaktaggelser fran palsomraden," Norsk Geografisk Tidsskrift, Vol. 13, No. 5-6, 1961, pp. 212-227.

"A type of circular lakes in northernmost Norway," Geografiska Annaler, Vol. 51A, 1969, pp. 1-12.

"Pingos i yttre delen an Adventdalen," Norsk Polarinstitutt Skrifter, 1971, pp. 168-174.

"Structural observations on the minerogenic core of a pala," Svensk Geografisk Arsbok, Vol. 40, 1968, pp. 138-142.

"Pingo problems in the Scandinavian countries," Biuletyn Peryglacjalny, Vol. 26, 1976, pp. 33-40.

Tarnocai, C. and J.A. Netterville. "Some characteristics of a pingo in the Simpson Peninsula," Canadian Joumal of Earth Sciences, Vol. 13, 1976, pp. 490-492.

Thom, G. "Disruption of bedrock by the growth and collapse of ice lenses," Journal of Glaciology, Vol. 20, No. 84, 1978, pp. 571-575. 
Van Autenboer, T. and W. Loy. "Pingos in northwest Spitsbergen," Norsk Polarinstitutt Arbok 1965, 1966, pp. 75.80.

Vernon, P. and O.L. Hughes. "Surficial geology, Dawson, Larsen Creek and Nash Creek map areas, Yukon Territory," Geological Survey of Canada Bulletin, No. $136,1966,25 \mathrm{pp}$.

Wang, S. and Yao, H. "On the pingos along both banks of the Qing-Shui River on Qinghai-Xizang plateau," Journal of Glaciology and Cryopedology, Vol. 3, No. 3, 1981, pp. 58-62.

Washburn, A.L. Periglacial processes and environments. London: Edward Arnold, $1973,320 \mathrm{pp}$.

Geocryology. A survey of periglacial processes and environments. London: Edward Arnold, 1979, 406 pp.

"Permafrost features as evidence of climatic change," Earth Science Reviews, Vol. 15,1980 , pp. $327-402$.

"Palsas and continuous permafrost," in: Permafrost. Fourth International Conference Proceedings. Washington: National Academy Press, 1983, pp. 1372 1377.

White, S.E., G.M. Clark and A. Rapp. "Palsa localities in Padjelanta National Park, Swedish Lappland," Geografiska Annaler, Vol. 51 A, 1969, pp. 97-103.

Williams, P.J. "Properties and behaviour of freezing soils," Norwegian Geotechnical Institute Publication, No. 72, 1967, 119 pp.

"Ice distribution in permafrost profiles," Canadian Journal of Earth Sciences, Vol. 5, 1968, pp. 1381-1386.

Wirthmann, A. Die Landformen/der Edge-Insel in Südostspitzbergen . The landforms of Edge Island in southeast Svalbard]. Wiesbaden, 1964.

Wrammer, P. "Studier av palsmyrar i Laivadalen, Lappland," Meddelelser fron Göteborgs Universitets Geografiska Institutionen, No. 86, 1967,659 pp.

-Palslika bildningar $\mathfrak{i}$ mineraljord naagra iaktaggelser fran taavavuoma, Lappland," Göteborg Universitet naturgeografiska Institutionen, Guni rapport, No. 1, 1972,59 pp.

Zoltai, S.C. "Southern limit of permafrost features in peat landforms, Manitoba and Saskatchewan," Abstracts of papers, Geological Association of Canada Annual Meeting, Winnipeg, 1970, p. 58.

and C. Tarnocai. "Properties of a wooded palsa in Northern Manitoba," Arctic and Alpine Research, Vol. 3, No. 2, 1971, pp. 115-129. 